\title{
Impact of sulfur dust application on the abundance of two important coccinellid predators in marrow fields
}

\author{
Mohamed Ahmed Gesraha* (D) and Amany Ramadan Ebeid
}

\begin{abstract}
Background: For the sake of environmental safety, many sulfur formulations were recommended in many Integrated Pest Management (IPM) programs to protect, particularly, edible vegetables and fruit trees from insect and mite pests as well as plant pathogenic diseases. Such formulations, at the recommended application rates, proved to be safer to mammals. Regarding their safety to beneficial arthropods, diversified results were reported. This study was designed to investigate and evaluate the impact of sulfur formulation against some natural enemies naturally prevailing in some vegetable crops.

Method: Sulfur formulation (Agricultural Sorell-98\%) was recommended by the Ministry of Agriculture, Egypt, as a protectant for vegetable crops against some plant diseases and piercing-sucking pests (aphis, whiteflies, thrips, and mites) at the rate of $30 \mathrm{~kg} / F e d d a n 30$ days post plantation. The experiment was undertaken in two similar rectangle areas during the season (2016/2017). Each area about $700 \mathrm{~m}^{2}$ was sown with marrow plant. The first area was divided longwise into two halves, each half comprises six rows and divided horizontally into four plots each about $75 \mathrm{~m}^{2}$. Similar plots were done in the second area but no treatments were made (check area). Monitoring the density fluctuations of the natural enemies in the target areas was undertaken at certain intervals (just before dusting, 2, 12, 24, 48, and $72 \mathrm{~h}$ and 7 days after application) and achieved early in the morning $(7 \mathrm{am})$. Fifty plants were inspected per plot per time interval in treated and untreated areas. The average number of each natural enemy/time interval and percent increase or decrease in the population density in the treated half and the untreated one were calculated.

Results: The obtained data revealed that the least number of the prevailing adults was recorded at the treated plot after $2 \mathrm{~h}$ post treatment for Coccinella and after $12 \mathrm{~h}$ for Stethorus adults. In addition, it could be observed that the mean number of the recorded adults occurred in the untreated plot of the first area was increased significantly than that of the untreated second area at 12 and $48 \mathrm{~h}$ and after 1 week post treatment, this could be referred to the following: when the treated plot was sprayed with sulfur compound, most of the prevailing adults escaped from the dust and migrate to the untreated plot or other clean plants (untreated plot or other surrounding plants), then they returned back gradually to the treated plot.

Conclusion: The obtained results clarify that the intelligent handling of sulfur formulations in order to control some pests and plant diseases with minimal or harmless effects towards the adult predators under investigation must be taken in consideration; thus, this could be more favorable to keep the environment clean and non-polluted. In addition, results throw light on that Stethorus punctillum was more susceptible than Coccinella undecimpunctata especially for the sulfur residues on treated plants.
\end{abstract}

Keywords: Sulfur formulation, Coccinella, Stethorus, Marrow

* Correspondence: mgesraha@gmail.com

Pests and Plant Protection Department, National Research Centre, 33

El-Bohouth Street, Dokki, Cairo 12622, Egypt 


\section{Background}

For the sake of environmental safety, many sulfur formulations were recommended in many Integrated Pest Management (IPM) programs to protect, particularly, edible vegetables and fruit trees (A Guide to Managing Tree Fruit Pests in Home Garden 2017) from insect and mite pests as well as plant pathogenic diseases. Such formulations, at the recommended application rates, proved to be safer to mammals.

Regarding their safety to beneficial arthropods, diversified results were reported. Cohen et al. (1996) reported that sulfur was somewhat toxic to Aphelinus mali (Haldeman), a parasite of Eriosoma lanigerum (Hausmann) aphid under laboratory conditions. Araya et al. (1997b) mentioned that treatment with sulfur formulations applied at the flowering period was less effective on Rachiplusia nu larvae and was repellent against some other predators such as coccinellids and nabids. Kumar and Singh (2002) found that wettable powder of sulfur is toxic to the most important predator of mite, Hersutella thompsonia, in India. Newman et al. (2004) considered that lime sulfur residues caused 80-90\% mortality of the leafroller parasitoid, Dolichogenidae tasmanica adults, in New Zealand.

On the other side, some researches have showed that the repellency of the hymenopterous parasitoid, Polistes bussoni of Rachiplusia nu (Guenee), caused by sulfur applications is slight and caused an insignificant reduction in the parasitoid population (Araya et al. 1997a). Wetzel and Dickler (1994) found that the sulfur product NAB (The NAB pesticides, described as a sulfur product, and pyrethrin + piperonyl butoxide (Spruzit)) caused a slight reduction $(0-17 \%)$ of parasitization of Trichogramma dendrolimi Matsumura as compared with $85-99 \%$ for parathion.

This work is to investigate the effects of sulfur dust application on the density fluctuations of the two coccinellid natural enemies existing in fields of some vegetable crops. Monitoring of the population density of such useful insects in treated areas as well as untreated areas surrounding or adjacent to the treated ones may be of great value for prediction of a useful IPM program.

\section{Methods}

Sulfur formulation powder (Agricultural Sorell-98\%) was used. It was produced by the Kafer El-Zayat Company for Chemical Insecticides Production, Egypt. It is recommended by the Ministry of Agriculture, Egypt, as a protectant for vegetable crops against some plant diseases and piercing sucking pests (aphis, whiteflies, thrips, and mites). Dusting of sulfur was carried out using Chapin 5000 16-Ounce Hand Rose and Plant Duster Sprayer Model \#5000 duster 30 days post sowing.

\section{Field experiment}

Agricultural practices in Manawat village, Giza Governorate, Egypt, usually include dusting many vegetable crops by the sulfur formulation, Sorell-98\%, at the rate of $30 \mathrm{~kg} /$ Feddan at certain post plantation period (30 days) according to the Ministry of Agriculture recommendations. The experiment was undertaken in two similar rectangle areas during the season (2016/2017). Each area (about $700 \mathrm{~m}^{2}$ ) was sown with a marrow plant in hills (2-3 seeds/hole) and $50 \mathrm{~cm}$ apart from each side. The first area was divided lengthwise into two halves, each half comprises six rows and divided horizontally into four plots each about $75 \mathrm{~m}^{2}$. Thinning was done after sowing. The plants were removed from two rows between the two halves and one row between every two plots. Similar plots done in the second area but no treatments were done. Sulfur dust (Sorell-98\%) was applied at the recommended concentration (30 kg/Feddan) to plots in the first half of the first area. The other areas were left untreated.

Monitoring the density fluctuations of the most efficient natural enemies prevailing in the target areas was undertaken at certain intervals (just before dusting, 2, $12,24,48$, and $72 \mathrm{~h}$ and 7 days after application). This was achieved early in the morning $(7 \mathrm{am})$. Fifty plants were inspected per plot per time interval in treated and untreated areas.

The mean number of each natural enemy/50 plants/ plot/time interval and percent increase $(+)$ or decrease $(-)$ in the population density in the treated half and the untreated one were calculated at each time interval. This was achieved to examine how far the effect of such application may reflect or inflict on the density of natural enemies in untreated cultivation surrounding or adjacent to treated one.

\section{Statistical analysis}

Analysis of variance (ANOVA) F-test was applied. Duncan multiple range test (Duncan 1955) was carried out to differentiate between means. Percentage of increase or decrease was calculated using a free online tool to calculate percentages (https://percentagecalculator.net/).

\section{Results}

\section{Effect of sulfur dust on Coccinella undecimpunctata}

Table 1 illustrates the effect of sulfur dust application at the recommended rate $(30 \mathrm{~kg} /$ Feddan $)$ on $C$. undecimpunctata population density in marrow cultivations. The average density in the treated plot, just before application (at $7 \mathrm{am}$ ), was 16.20 adults/50 plants/plot. The corresponding density in the untreated plot, adjacent to the treated one, was 18.20 adults/50 plants/plot. Two hours after application (at $9 \mathrm{am}$ ), a sharp drop in the predator density averaged 6.80 adults/50 plants which represents about $58.02 \%$ reduction. In the untreated area, the 
Table 1 Population densities of Coccinella undecimpunctata adults in untreated and sulfur-treated marrow cultivations

\begin{tabular}{|c|c|c|c|c|}
\hline \multirow[t]{3}{*}{ Inspection periods (hours) } & \multicolumn{2}{|l|}{ First area } & \multirow[t]{2}{*}{ Second area } & \multirow[t]{3}{*}{$F$ value (1) } \\
\hline & \multicolumn{2}{|c|}{ Average number of adults/50 plants/plot \pm SE } & & \\
\hline & Treated plot & Untreated plot & Untreated area & \\
\hline$(-) 0$ & $16.20 \pm 0.86 \mathrm{aAB}$ & $18.20 \pm 0.86 \mathrm{aC}$ & $17.00 \pm 0.71 \mathrm{aB}$ & $1.535^{\mathrm{NS}}$ \\
\hline (+) 2 & $6.80 \pm 1.07 \mathrm{bD}$ & $29.60 \pm 1.50 \mathrm{aAB}$ & $27.80 \pm 1.85 \mathrm{aA}$ & $70.474^{* *}$ \\
\hline (+) 12 & $8.40 \pm 1.36 \mathrm{cD}$ & $32.80 \pm 0.86 \mathrm{aA}$ & $29.20 \pm 1.16 \mathrm{bA}$ & $132.102^{* *}$ \\
\hline (+) 24 & $9.20 \pm 1.16 \mathrm{bCD}$ & $31.00 \pm 2.92 \mathrm{aA}$ & $30.80 \pm 1.50 \mathrm{aA}$ & $38.983^{* *}$ \\
\hline (+) 48 & $13.80 \pm 2.69 \mathrm{bBC}$ & $25.20 \pm 1.66 \mathrm{aB}$ & $18.60 \pm 1.21 b B$ & $8.591^{* *}$ \\
\hline (+) 72 & $17.20 \pm 1.56 \mathrm{aAB}$ & $18.40 \pm 1.03 \mathrm{aC}$ & $15.80 \pm 1.69 \mathrm{aB}$ & $0.801^{\text {NS }}$ \\
\hline (+) 7 days & $20.40 \pm 1.72 \mathrm{aA}$ & $14.00 \pm 2.35 \mathrm{aC}$ & $10.80 \pm 1.50 \mathrm{bc}$ & $6.699^{*}$ \\
\hline F value (2) & $10.348^{* *}$ & $17.551^{* *}$ & $29.961^{* *}$ & \\
\hline
\end{tabular}

Before application (-), after application $(+)$, df $1=2,9$, df $2=6,21$. Data in rows with the same small letters are not significantly different ( $P$ value at $5 \%$ ). Data in columns with the same capital letters are not significantly different $(P$ value at $5 \%)$. ${ }^{*}$ Significant, **highly significant, and $N S$ insignificant

corresponding figure at 9 am, a slight increase was observed $(27.80 \%)$ (Table 1$)$ that represented $71.76 \%$ increase (Table 1 and Fig. 1). Thereafter, densities in treated plot showed population reduction ranged between 48.15 and $14.81 \%$ within 2 days post application, indicating that the migrated predator return back gradually (Table 2). Starting with $72 \mathrm{~h}$ and 1 week post treatment, the percentage of population density was increased, i.e., 6.17 and 25.93\% were observed (Table 2 and Fig. 1). This is contrary to that occurred in the untreated plot adjacent to treated ones as the average densities of the predator indicated ( 80.22 to $38.46 \%$ increase in the population density within the same period, respectively, which recorded only $1.10 \%$ after $72 \mathrm{~h}$ post treatment (Table 2 and Fig. 1). The decrease in population reached $23.08 \%$ after 1 week was recorded. Nearly the same trend was observed for the untreated second area (Table 2 and Fig. 1).

Comparing the density of the predator in the treated, untreated adjacent treated plots, and untreated plots in the second area, the $F$-test analysis showed that at $0 \mathrm{~h}$ of treatment, there was an insignificant difference between them $(F=1.535)$ (Table 1$)$. The same trend was observed at $72 \mathrm{~h}$ post treatment, where the mean number of population was statistically insignificant too for treated plots, untreated plots of the first area, and untreated one in the second area $(F=0.801)$ (Table 1$)$. On the other hand, the rest of inspection periods post treatment exhibits significant differences between the three examined plots, where the treated plot recorded the least mean number of the population $\left(F=70.474^{* *}, 132.102^{* * *}\right.$, $38.983^{* * *}, 8.591^{* *}$, and $6.699^{*}$, respectively) (Table 1 ), revealed that the least number of the prevailing adults was recorded at the treated plot, except at $72 \mathrm{~h}$ and 1 week inspection periods. In addition, it could be observed that the mean number of the recorded adults occurred in the untreated plots of the first area was insignificantly increased than that of the untreated plots of the first area and was increased significantly after 1 week post treatment for plots of the second area; this could be referred to the following: when the treated plot was sprayed with sulfur compound, most of the prevailing adults escaped from the dust and migrate to the untreated plot or other clean plants (i.e., untreated plots or other surrounding plants), then they return back gradually to the treated plots after more than $48 \mathrm{~h}$ (Table 1 and Fig. 1).

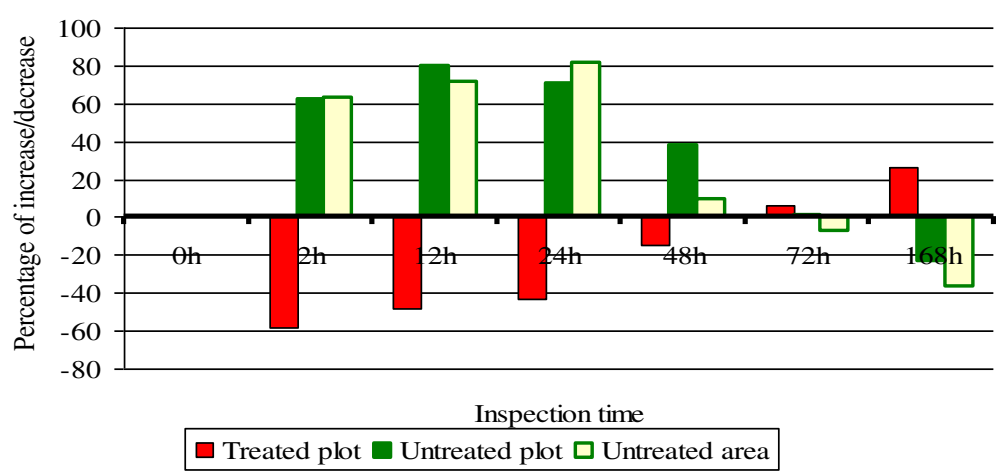

Fig. 1 Percentage of density fluctuations of Coccinella undecimpunctata adults in untreated and sulfur-treated marrow cultivations 
Table 2 Percentage of increase or decrease in population densities of Coccinella undecimpunctata adults in untreated and sulfur-treated marrow cultivations

\begin{tabular}{llll}
\hline $\begin{array}{l}\text { Inspection } \\
\text { periods } \\
\text { (hours) }\end{array}$ & $\begin{array}{l}\text { First area } \\
\text { \% Increase/decrease }\end{array}$ & $\begin{array}{l}\text { Second area } \\
\text { Untreated area }\end{array}$ \\
\cline { 2 - 3 } & - & - & \\
\hline$(-) 0$ & -58.02 & +62.64 & - \\
$(+) 2$ & -48.15 & +80.22 & +63.53 \\
$(+) 12$ & -43.21 & +70.33 & +81.76 \\
$(+) 24$ & -14.81 & +38.46 & +9.41 \\
$(+) 48$ & +6.17 & +1.10 & -7.06 \\
$(+) 72$ & +25.93 & -23.08 & -36.47 \\
\hline (+) 7 days & & &
\end{tabular}

Before application (-), after application (+)

\section{Effect of sulfur dust on Stethorus punctillium}

The corresponding figure for S. punctillium in marrow field could be summarized as follows: the average density in the treated plot at zero time, just before application, was 6.75 adults/50 plants/plot, while in untreated plot, adjacent to the treated one, was 6.50 adults, and at the second untreated area, it was 4.75 adults (Table 3). Two hours post application, the recorded predator density averaged 1.25 adults/50 plants which represent about $81.48 \%$ reduction in population (Table 4 and Fig. 2). In the second untreated area, the corresponding figure at 9 am was $15.79 \%$ reduction too in population number. Thereafter, densities in treated plots showed a reduction in population ranged between 100.00 and $66.67 \%$ within 2 days post application and continuously to reach to $62.96 \%$ after 1 week. This was contrary to that occurred in the untreated plot adjacent to the treated one as the average densities of the predator was 34.62 to $26.92 \%$ increase in the population density within the same period,
Table 4 Percentage of increase or decrease in population densities of Stethorus punctellium adults in untreated and sulfur-treated marrow cultivations

\begin{tabular}{llll}
\hline $\begin{array}{lll}\text { Inspection } \\
\text { periods } \\
\text { (hours) }\end{array}$ & $\begin{array}{l}\text { First area } \\
\text { Treated plot }\end{array}$ & $\begin{array}{l}\text { Second area } \\
\text { \% Increase/decrease }\end{array}$ & \\
\hline$(-) 0$ & - & - & - \\
$(+) 2$ & -81.48 & -30.77 & -15.79 \\
$(+) 12$ & -100.00 & +34.62 & +31.58 \\
$(+) 24$ & -88.89 & +7.69 & -10.53 \\
$(+) 48$ & -66.67 & +26.92 & +52.63 \\
$(+) 72$ & -70.37 & +11.54 & +68.42 \\
$(+) 7$ days & -62.96 & +7.69 & +42.11
\end{tabular}

Before application (-), after application (+)

respectively, which reached $7.69 \%$ after 1 week (Table 4 and Fig. 2). On the other hand, the population density of S. punctillium adults in the untreated second area recorded increasing ranged between +31.58 and $+52.63 \%$ within the period started from $2 \mathrm{~h}$ until $48 \mathrm{~h}$ post treatment, then changed gradually to reach $42.11 \%$ after 1 week (Table 4 and Fig. 2).

Evaluating the predator's density in treated and untreated plots and untreated plots in the second area showed that only at 0 time of application there was the insignificant difference $(F=0.380)$, while in all other inspection periods, there were significant differences between them (Table 3).

In addition, the mean number of the recorded adults occurred in the untreated plots of the first area was somewhat increased or nearly as the same number compared to the untreated second area, this could be explained as follows: when the treated plots were sprayed, most of the prevailing adults migrate to the untreated plots escaping from the dust to other clean plants

Table 3 Population densities of Stethorus punctellium adults in untreated and sulfur-treated marrow cultivations

\begin{tabular}{|c|c|c|c|c|}
\hline \multirow[t]{3}{*}{ Inspection periods (hours) } & \multicolumn{2}{|l|}{ First area } & \multirow[t]{2}{*}{ Second area } & \multirow[t]{3}{*}{$F$ value (1) } \\
\hline & \multicolumn{2}{|c|}{ Average number of adults/50 plants/plot \pm SE } & & \\
\hline & Treated plot & Untreated plot & Untreated area & \\
\hline$(-) 0$ & $6.75 \pm 2.06 \mathrm{aA}$ & $6.50 \pm 2.22 \mathrm{aB}$ & $4.75 \pm 0.48 \mathrm{aBC}$ & $0.380^{N S}$ \\
\hline (+) 2 & $1.25 \pm 0.75 \mathrm{bB}$ & $4.50 \pm 1.32 \mathrm{aB}$ & $4.00 \pm 0.71 \mathrm{abC}$ & $4.267^{*}$ \\
\hline (+) 12 & $0.00 \pm 0.00 \mathrm{bB}$ & $8.75 \pm 1.25 \mathrm{aB}$ & $6.25 \pm 0.75 \mathrm{aABC}$ & $28.676^{* *}$ \\
\hline (+) 24 & $0.75 \pm 0.25 b B$ & $7.00 \pm 1.58 \mathrm{aB}$ & $4.25 \pm 1.18 \mathrm{aC}$ & $7.437^{* *}$ \\
\hline (+) 48 & $2.25 \pm 0.85 \mathrm{bB}$ & $8.25 \pm 1.31 \mathrm{aB}$ & $7.25 \pm 1.44 \mathrm{aAB}$ & $6.857^{*}$ \\
\hline (+) 72 & $2.00 \pm 0.41 \mathrm{bB}$ & $7.25 \pm 1.11 \mathrm{aB}$ & $8.00 \pm 0.82 \mathrm{aA}$ & $15.545^{* *}$ \\
\hline (+) 7 days & $2.50 \pm 0.87 \mathrm{bB}$ & $7.00+1.22 \mathrm{aB}$ & $6.75 \pm 0.63 \mathrm{aABC}$ & $7.252^{* *}$ \\
\hline$F$ value (2) & $5.147^{* *}$ & $0.859^{\mathrm{NS}}$ & $2.957^{*}$ & \\
\hline
\end{tabular}

Before application (-), after application $(+)$, df $1=2,9$, df $2=6,21$. Data in rows with the same small letters are not significantly different $(P$ value at $5 \%)$. Data in columns with the same capital letters are not significantly different ( $P$ value at $5 \%)$. ${ }^{*}$ Significant, **highly significant, and $N S$ insignificant 


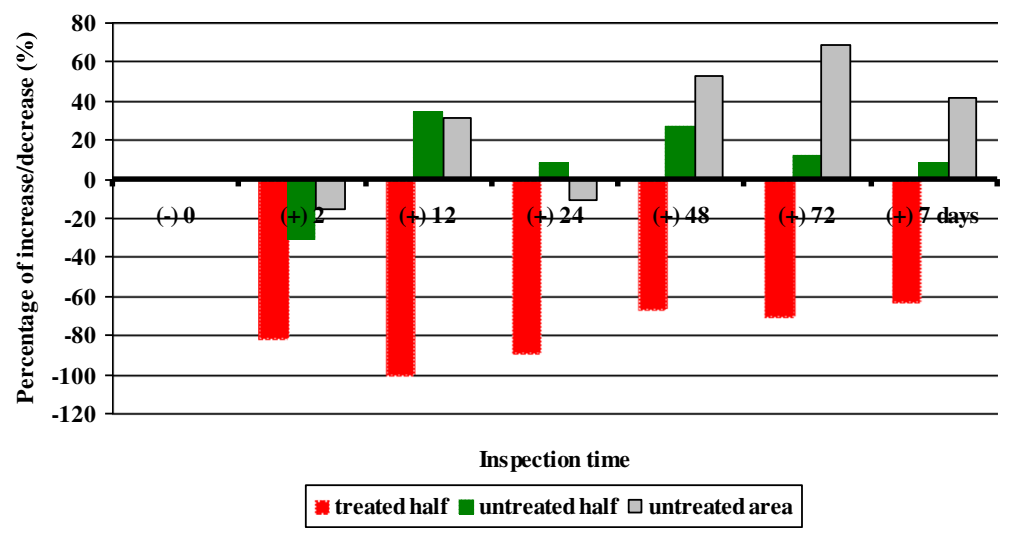

Fig. 2 Percentage of density fluctuations of Stethorus punctellium adults in untreated and sulfur-treated marrow cultivations

(untreated plots and/or other surrounding plants), then they did not return back to the treated plot till the end of the experiment (Table 4 and Fig. 2).

\section{Discussion}

\section{As for Coccinella undecimpunctata}

The obtained results were in accordance with that reported by Araya et al. (1997b) on their work on Rachiplusia nu larvae, where the sulfur compound was repellent against adults of other predators (nabids and coccinellids). Also, results were matched with that reported by Zappala et al. (2012) for their work on Nesidiocoris tenuis as a natural enemy (predator) for Tuta absoluta in tomato plantation using two sulfur formulations. Sulfur formulation applied weekly on tomato seedlings artificially infested with $T$. absoluta in greenhouse reduced significantly the rate of infestation and was played as a repellent effect on oviposition. In addition, they mentioned that residual effect test conducted with $N$. tenuis, revealed that only dustable sulfur was moderately harmful as a fresh residue and slightly harmful as 7 days post treatment; no effects were recorded when the predator was exposed 14 days post treatment. Our obtained results were partially matched with Biondi et al. (2012) for their work on the predator Orius laevigatus, where they mentioned that wettable sulfur (sulfur WP) proved to be harmless (Ex $<30 \%$, IOBC class 1 ) with mortality and reproductive capacity levels similar to what was recorded in untreated control group. Both sulfur compounds did not induce mortality in predators, but predator reproductive capacity was reduced by sulfur DP in case of exposure to 1-h-old residues. This result may be related to the activity of the compound as an oviposition repellent or as an egg dryer. On the other side, our results were in contrast with that reported by Daniel et al. (2001) on their work for estimation the side effects of sulfur formulation on some predatory mites, i.e., Typhlodromus pyri, in field trails on apple, vine, and plums to control some pests (Panonychus ulmi, Tetranychus urticae and thrips).

\section{As for Stethorus punctellium}

Regarding sulfur compounds' safety to beneficial arthropods, diversified results were reported. Generally, there are negative impacts on predatory insects from sulfur compounds' application as mentioned by many authors, but some other researchers gave opposite results; it is presumably according to some factors, i.e., time of application, insect stage, temperatures, humidity as well as the nature structure of plant leaves surface, and finally, the residues on the applied sulfur compound.

Bioassays and field studies carried out by James and Coyle (2001) and Gent et al. (2009) have demonstrated that sulfur and other fungicides are innocuous to most of the predatory insects. In addition, no evidence of suppressed populations of predacious insects was found.

James (2004) studied the safety of selected miticides against three predatory mite and two lady beetle species and found that hexythiazox, bifenazate, and spirodiclofen were found safer than other selected miticides to the Stethorus picipes. It was found that pymetrozine were found safer than other selected insecticides. They also studied the safety of selected fungicides and found that mycobutanil and wettable sulfur were safer than other fungicides to the predator S. picipes.

In addition, Godhani (2014) mentioned that sulfur formulations at any of the tested concentrations were safer to Stethorus spp.

In contrast, our results were partially matched with that reported by Biddinger et al. (2009), as they mentioned that the use of chemical control, even insect growth regulators or elemental sulfur, can be very harmful to Stethorini and other biological agents. 
Woods et al. (2012) mentioned that a significant differences in the abundance of Stethorous spp.-as predatory insect-in the levels of leaves that are treated with sulfur compared with untreated ones, presumably the positive effect of sulfur on predatory insects, were associated with greater prey abundance provoked by sulfur treatment effects, i.e., sulfur kill the predator, which gave the opportunity to the prey to propagate.

Our observations about the unreturned back of the Stethorus adults for more than 2-3 weeks to the treated plot matched with that reported by Gent (2016) where he mentioned that sulfur was toxic to Stethorus adult. This could be one of the reasons concerned with that of Stethorus adults which did not return back to the treated plot.

\section{Conclusion}

Sulfur formulation (Sorell-98\%) was investigated as a protectant for marrow plant against some insect, mite pests, and plant diseases. The experimental results of population density fluctuation suggested that the predator Coccinella undecimpunctata would escape from the sulfur dust and gradually return after 48 -h post treatment, while the second predator Stethorus punctillium would migrate and never return back after sulfur application during the experimental period. For that, the intelligent handling of sulfur formulations in order to control some pests and plant diseases with minimal or no harmful effects towards the adult predators must be taken into consideration; thus, this could be more favorable to keep the environment clean and non-polluted. In addition, results throw light on that Stethorus punctillum was more susceptible than Coccinella undecimpunctata especially for the sulfur residues on treated plants.

The obtained results clarify that the intelligent handling of sulfur formulations in order to control some pests and plant diseases with minimal or no harmful effects towards the adult predators must be taken into consideration; thus, this could be more favorable to keep the environment clean and non-polluted. In addition, results throw light on that Stethorus punctillum was more susceptible than Coccinella undecimpunctata especially for the sulfur residues on treated plants.

\section{Acknowledgements}

The authors are very grateful to Professor Doctor $\backslash$ Matter, M.M. and Late Professor Doctor $\backslash$ Farag, N.A., and for all colleges, especially for Mr. $\backslash$ Hussein Saad Hussein, Pests and Plant Protection Department, National Research Centre, for their valuable advises and help provided.

\section{Funding}

This work was personally funded by the authors.

\section{Availability of data and materials}

All dataset on which abstracted of the study have been drawn are presented in the main manuscript. All tables or figures have not been published anywhere else before. All data and materials are available.

\section{Significant statement}

This study is important for the clean environment free of the pollution of chemical insecticides, create new agents from local available materials safe, easy preparing, cheap, possible use in combination with other biological control method of IPM program, decrease build up resistance strains of the insect.

\section{Authors' contributions}

EAR collected the publications needed, shared in constructing the tables and figures and interpreting the results, edited the manuscript, and revised the final form. GMA carried out the statistical analysis, interpreted the analyzed data, obtained the results, constructed the tables and figures, and edited the manuscript. Both authors read and approved the final manuscript.

Ethics approval and consent to participate

Not applicable

\section{Consent for publication}

Not applicable

\section{Competing interests}

The authors declare that they have no competing interests.

\section{Publisher's Note}

Springer Nature remains neutral with regard to jurisdictional claims in published maps and institutional affiliations.

Received: 25 September 2018 Accepted: 21 January 2019

Published online: 21 February 2019

\section{References}

A Guide to Managing Tree Fruit Pests in Home Garden (2017). BC Ministry of Agriculture 200-1690 Powick Rd Kelowna BC V1X 2H2. https://www2.gov.bc. ca/assets/gov/farming-natural-resources-and-industry/agriculture-andseafood/animal-and-crops/plant-health/fruitspray.pdf

Araya C, Arretz VP, Guerrero SMA, Lamborot CL (1997a) Observation of Polistes buyssoni (Brethes) (Hymeniptera: Vrspidae), predator of Rachiplusia nu (Guenee) (Lepidoptera: Noctuidae) larvae on field beans in the metropolitan region, Chile. c 17(1/2):19-23

Araya JE, Arretz VP, Lamborot CL, Guerrero SMA (1997b) Natural control by predators of Rachiplusia nu (Guenee) (Lepidoptera: Noctuidae) on Phaseolus beans in Central Chile. Z Pflanzenk Pflanzen 104:147-152

Biddinger DJ, Weber DC, Hull LA (2009) Coccinellidae as predators of mites: Stethorini in biological control. Biol Control 51:268-283

Biondi A, Desneux N, Siscaro G, Zappalà L (2012) Using organic-certified rather than synthetic pesticides may not be safer for biological control agents: selectivity and side effects of 14 pesticides on the predator Orius laevigatus. Chemosphere 87:803-812

Cohen H, Horowrrz AR, Nestel D, Rosen D (1996) Susceptibility of the woolly apple aphid parasitoid, Aphelinus mali (Hym.: Aphelinidae), to common pesticides used in apple orchards in Israel. Entomophaga 41(2):225-233

Daniel C, Haeseli A, Weibel F (2001) The side effects of lime sulphur on predaceous arthropods, i.e. Typhlodromus pyri, and other leaf occupying arthropods. http://orgprints.org/2932/

Duncan DB (1955) Multiple ranges and multiple F-test. Biometrics 11:1-42

Gent DH (2016) Downy mildew: identification, lifecycle, and management. Forage Seed and Cereal Research Unit USDA-ARS Corvallis, Oregon https:// ag.purdue.edu/hla/Extension/Documents/2016_Hops_Workshop_pdfs/ 2016\%20GENT\%20Indiana\%20Disease\%20Talk.pdf

Gent DH, James DG, Wright LC, Brooks DJ, Barbour JD, Dreves AJ, Fisher GC, Walton VM (2009) Effects of powdery mildew fungicide programs on twospotted spider mite (Acari: Tetranychidae), hop aphid (Hemiptera: Aphididae), and their natural enemies in hop yards. Econ Entomol 102:274-286

Godhani HS (2014) Aspects of the biology of the ladybird beetle Stethorus pauperculus Weise (Coleoptera: Coccinellidae). Ms. C. Thesis. Navsari Agricultural University, India, p 202

James DG (2004) Beneficial arthropods in Washington vineyards: screening the impact of pesticides on survival and function. Final report for Washington State Commission for pesticide registration: March 2004

James DG, Coyle J (2001) Which pesticides are safe to beneficial insects and mites? Agr Environ News 178:12-14 
Kumar PS, Singh SP (2002) Wettable sulphur is toxic to Hirsutella thompsonii, the most important natural enemy of the coconut mite. Indian coconut journal. Coconut Dev Board Kochi India 33(1):1-2

Newman IC, Walker JTS, Rogers DJ (2004) Mortality of the leafroller parasitoid Dolichogenidae tasmanica (Hym:: Braconidae) exposed to orchard pesticide residues. N Z Plant Prot 57:8-12

Wetzel C, Dickler E (1994) Side effects of sulphur and natural pyrethroid on Trichrogramma dendrolimi Matsumura (Hym., Trichogrammatidae) in apple orchards. Bull OILB/SROP 17(10):123-131

Woods JL, Dreves AJ, Fisher GC, James DG, Wright LC, Gent DH (2012) Population density and phenology of Tetranychus urticae (Acari: Tetranychidae) in hop is linked to the timing of sulfur applications. Environ Entomol 41(3):621-635. https://doi.org/10.1603/EN11279

Zappala L, Siscaro G, Biondi A, Molla O, Gonzalez-Cabrera J, Urbaneja A (2012) Efficacy of sulphur on Tuta absoluta and its side effects on the predator Nesidiocoris tenuis. J Appl Entomol 136:401-409

\section{Submit your manuscript to a SpringerOpen ${ }^{\odot}$ journal and benefit from:}

- Convenient online submission

- Rigorous peer review

- Open access: articles freely available online

High visibility within the field

- Retaining the copyright to your article

Submit your next manuscript at $\boldsymbol{\nabla}$ springeropen.com 